\title{
Productive performance of blackberry cultivars in altitude region
}

\author{
Jéssica de Oliveira ${ }^{1}$ Maria do Céu Monteiro da Cruz ${ }^{1 *}$ Rodrigo Amato Moreira $^{1}$ \\ Miriã Cristina Pereira Fagundes ${ }^{1}$ Cintia Gonçalves Sena ${ }^{2}$
}

'Programa de Pós-graduação em Produção Vegetal, Universidade Federal dos Vales do Jequitinhonha e Mucuri (UFVJM), Campus JK, 39100-000, Diamantina, MG, Brasil. E-mail: mariceu@ufvjm.edu.br. *Corresponding author.

${ }^{2}$ Departamento de Agronomia, Universidade Federal dos Vales do Jequitinhonha e Mucuri (UFVJM), Campus JK, Diamantina, MG, Brasil.

\begin{abstract}
Information on the production performance of blackberry in less colder regions are fundamentals to the expansion of the cultivated area and extension of management practices for cultivars adapted to climate conditions in Brazil. The research was carried out with the aim to evaluate the productive performance of different blackberries cultivars in altitude region of $1,387 \mathrm{~m}$ with mild temperatures, situate at 18'14'56"S, 43'36'0'W, in Minas Gerais State, Brazil. It was carried during the seasons 2013/2014, 2014/2015 and 2015/2016. The blackberry cultivars evaluated were the following ones 'Brazos', 'Guarani', 'Tupy' and 'Xavante'. Flowering and harvesting of cultivars were evaluated as well as climatological data of the area in order to relate the number of hours of accumulated cold less than $13^{\circ} \mathrm{C}$, $10^{\circ} \mathrm{C}$ and $7.2^{\circ} \mathrm{C}$ with production and crop time. To determine the production, the mass of blackberries harvested per plant was measured. Production of blackberry cultivars was extended in altitude region with similar productivity to the other producing regions in Brazil. Productive performance of the cultivars varied according to the accumulation of cold hours with mild temperatures that occurred in cultivation region. 'Brazos', 'Guarani', 'Tupy' and 'Xavante'showed good adaptation, being 'Brazos' the cultivar most productive.

Key words: Rubus, cold hours, climate adaptation, productivity.
\end{abstract}

Desempenho produtivo de cultivares de amoreira-preta em região de altitude

RESUMO: As informações sobre o desempenho produtivo de amoreira-preta em regiões com menor ocorrência de frio são fundamentais para a ampliação da área de cultivada e adequação de práticas de manejo para as cultivares adaptadas as condições climáticas do Brasil. A pesquisa foi realizada com o objetivo avaliar o desempenho produtivo de diferentes cultivares de amoreira-preta em região com altitude

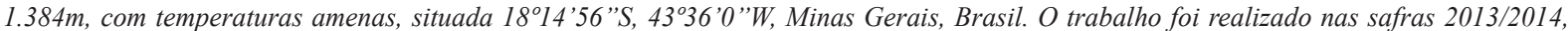
2014/2015 e 2015/2016. As cultivares de amoreira-preta avaliadas foram 'Brazos', 'Guarani', 'Tupy' e 'Xavante'. Durante o período de floração e de colheita das cultivares e os dados climatológicos da região para relacionar o número de horas de frio acumulado inferior a $13^{\circ} \mathrm{C}, 10^{\circ} \mathrm{C}$ e $7,2^{\circ} \mathrm{C}$ com a produção e a duração do ciclo. Para determinar a produção, avaliou-se a massa das amoras colhidas por planta em todas as colheitas realizadas A produção de cultivares de amora foi estendida em região de altitude com produtividade similar às demais regiões produtoras do Brasil. O desempenho produtivo das cultivares variou em função do acúmulo de horas de frio com temperaturas amenas que ocorreram na região do cultivo. As cultivares 'Brazos', 'Guarani', 'Tupy'e 'Xavante' apresentaram boa adaptação em região de altitude, sendo a 'Brazos' a cultivar mais produtiva.

Palavras-chave: Rubus, horas de frio, adaptação climática, produtividade.

\section{INTRODUCTION}

The blackberry is a specie that comes from regions with temperate climate. Therefore, the success of its culture is linked to the climatic elements, especially the temperature, which plays a key role in the production of the plant. However, each cultivar has their own particularity regarding the thermal needs and there may be differences in growth performance in various growing regions.

In Brazil, blackberry cultivation is recent and the expansion of cultivated areas depends of the cultivars adaptation to the climatic conditions of the region. The southern region is the largest producer in the country due to the occurrence of low temperatures during the winter. However, it will be 
necessary to intensify research to expand cultivation in new regions to meet the trend of market growth (ANTUNES et al., 2014).

The occurrence of low temperatures is important because the cold is necessary before flowering time, so the buds can raise and the new flowers can open in good conditions. Thus, it is extremely important to understand the fruiting behavior of the blackberry due to the climate changes during culture. The need for cold with temperatures below $7.2^{\circ} \mathrm{C}$ differs between cultivars and may, in some cases, abort culture in mild winter climates (CLARK et al., 2005).

Besides the influence of climatic elements, the inherent characteristics of the plant species may influence the production of blackberry (ANTUNES et al., 2000). Thus, information about the production potential in different regions is essential to help the expansion of growing areas of blackberry in Brazil.

Thus, studies on blackberry productive performance in new cultivation areas are a helpful tool to expand the production area in the country and to know the climatic adaptation and the production period of the cultivars in new sites. This contributes for a better recommendation adapted cultivars and the adoption of good management practices, harvest planning and marketing or fruit processing.

Thus, this study was conducted in order to evaluate the productive performance of different cultivars of blackberry during three years in altitude region with mild temperatures.

\section{MATERIALS AND METHODS}

The study has been carried out in a region located at a $1,387 \mathrm{~m}$ altitude, situate at $18^{\circ} 14^{\prime} 56^{\prime \prime} \mathrm{S}$, $43^{\circ} 36^{\prime} 0^{\prime}$ W, in Minas Gerais State, Brazil. The local climate, according to Köppen classification, is CWB. According to VIANELLO \& ALVES (2012), the region is classified to have a humid climate, meaning dry winters with mild temperatures and warm and rainy summers with a mean temperature of the hottest month below $22^{\circ} \mathrm{C}$. The average annual rainfall is $1,404 \mathrm{~mm}$. The rainy season from October to March represents $88 \%$ of the total rainfall during the year.

During evaluation time, the changes in temperature and precipitation from the growing site were recorded using an automatic station consisting of a central memory unit ("data logger"). This station is connected to various sensors in order to measure variations of different meteorological parameters (atmospheric pressure, temperature and relative humidity, precipitation, solar radiation, wind speed and direction) and integrates the values observed every minute and automatically every hour. It is installed on site, approximately $300 \mathrm{~m}$ away from the blackberry orchard.

The studied one-year-old blackberry (Rubus sp.) plants were 'Brazos', 'Guarani', 'Tupy' and 'Xavante'. Orchard was planted on Quartzarenic Neosol (EMBRAPA, 2013), which originates from sand deposits, with clay content less than $15 \%$ and its chemical characteristics in the depth in which the rootsystem of plants is most highly concentrated before planting were $\mathrm{pH}-\left(\mathrm{H}_{2} \mathrm{O}\right) 5.2, \mathrm{P} 1.6 \mathrm{mg} \mathrm{dm}^{-3} \mathrm{e}$ $\mathrm{K} 22 \mathrm{mg} \mathrm{dm}^{-3}$, Ca $0.6 \mathrm{cmolc} \mathrm{dm}^{-3}, \mathrm{Mg} 0.2 \mathrm{cmolc} \mathrm{m}^{-3}$, Al $0.6 \mathrm{cmolc} \mathrm{dm}^{-3}$, cation exchange capacity $(\mathrm{pH} 7)$ $4.6 \mathrm{cmolc} \mathrm{dm}^{-3}$, aluminum saturation $41 \%$, base saturation $19 \%$ and organic matter $1.2 \%$

The conducting of plants was in espaliers with a height of $0.8 \mathrm{~m}$ above ground have been used, with two parallels wires lines spaced $0.5 \mathrm{~m}$ away each other. Planting spacing consisted of $0.80 \mathrm{~m}$ between plants in the planting row and $2.50 \mathrm{~m}$ in the inter-row spacing lines. Preparation of the area and the management practices and fertilizing were performed according to soil chemical analysis and the recommendation for blackberry.

In each seasonal year, 2013/2014, 2014/2015 and 2015/2016, visual observations were taken at flowering and harvesting to determine the cycle duration of cultivars, and to determine the number of accumulated cold hours below $13^{\circ} \mathrm{C}, 10^{\circ} \mathrm{C}$ and $7.2^{\circ} \mathrm{C}$ before issuing buds emission during flowering stage of cultivars were calculated, from the daily temperature data.

Production was calculated throughout the harvest period, from the mass of harvested blackberries. Regarding productivity ( $\left.\mathrm{t} \mathrm{ha}^{-1}\right)$, it was calculated taking into account the crop yield and plant density. The experimental design was randomized blocks, with four blackberry cultivar studied; five blocks and ten plants per experimental unit.

Then, data were analyzed through analysis of variance and means comparison with the Tukey test at a $5 \%$ probability of error level, to compare the crop yield.

\section{RESULTS AND DISCUSSION}

\section{a) Effect of number of cold hours in blackberry flowering and harvesting}

In table 1, differences in flowering and harvesting periods are presented for all blackberry cultivars. From table 3, differences among varieties were observed during the three production cycles regarding the plant production and productivity. 
Table 1 - Flowering period (FP) and harvest period (HP) in 2013/14, 2014/2015 and 2015/2016 of blackberry cultivars in altitude region with mild temperatures.

\begin{tabular}{|c|c|c|c|c|c|c|}
\hline \multirow{2}{*}{ Cultivar } & \multicolumn{6}{|c|}{ 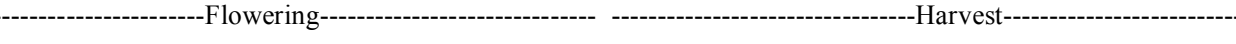 } \\
\hline & Begin & End & FP (days) & Begin & End & HP (days) \\
\hline \multicolumn{7}{|l|}{ 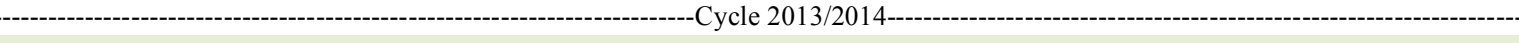 } \\
\hline 'Brazos' & $04 / 26$ & $01 / 20$ & 264 & $06 / 10$ & $02 / 24$ & 254 \\
\hline 'Guarani' & $09 / 30$ & $01 / 20$ & 140 & $11 / 13$ & $03 / 24$ & 131 \\
\hline ‘Tupy’ & $09 / 21$ & $01 / 26$ & 125 & $11 / 26$ & $03 / 27$ & 121 \\
\hline 'Xavante' & $09 / 25$ & $01 / 15$ & 110 & $11 / 03$ & $02 / 20$ & 107 \\
\hline \multicolumn{7}{|c|}{ - } \\
\hline 'Brazos' & $09 / 04$ & $12 / 18$ & 105 & $10 / 20$ & $01 / 26$ & 128 \\
\hline 'Guarani' & $08 / 19$ & $01 / 26$ & 143 & $10 / 30$ & $02 / 09$ & 102 \\
\hline ‘Tupy’ & $09 / 15$ & $01 / 28$ & 135 & $10 / 13$ & $02 / 09$ & 115 \\
\hline 'Xavante' & $09 / 01$ & $01 / 28$ & 150 & $10 / 10$ & $02 / 09$ & 118 \\
\hline \multicolumn{7}{|c|}{ 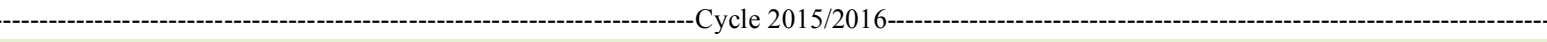 } \\
\hline 'Brazos’ & $08 / 18$ & $01 / 20$ & 155 & $10 / 19$ & $02 / 26$ & 131 \\
\hline 'Guarani' & 09/03 & $01 / 28$ & 147 & $11 / 04$ & $02 / 26$ & 115 \\
\hline ‘Tupy’ & $09 / 28 /$ & $02 / 02$ & 128 & $11 / 04$ & $02 / 26$ & 115 \\
\hline 'Xavante' & 09/09 & $01 / 29$ & 142 & $11 / 04$ & $02 / 26$ & 115 \\
\hline
\end{tabular}

Regarding the 2013/2014 season, 'Brazos' anticipated flowering, beginning in April and ending in January, thus, lasting 264 days. Harvest of fruits lasted 254 days (Table 1), due to the short time between fertilization of flowers and fruit ripening, which is approximately 30 days.

Results observed for a longer period of 'Brazos' production (Table 1) is due to the anticipation of its flowering, which resulted in extension of its production compared to the other blackberry cultivar. The duration and the time of production observed in this study differed from the behavior showed by these cultivars in other growing regions. Comparing 'Brazos' behavior in regions that have colder weather, as in the south of Brazil, the harvest of blackberries of this cultivar occurred between the second half of November and the first half of January, with an average 54 days duration (ANTUNES et al., 2010).

Differences in the cycle duration of 'Brazos' cultivar were observed in the following harvests, evidencing that the flowering of the first year was atypical for this cultivar. In 2014/2015 season, 'Brazos' flowered from September to December, five months later in relation to the previous harvest, lasting 105 days. The harvest was from October to January, lasting 128 days. In 2015/2016 production cycle, 'Brazos' began flowering in August, while the other cultivars flowering occurred from September. The flowering period of 'Brazos' lasted for 155 days, ending in January 2016. The harvest of this blackberry cultivar was carried out by 131 days, between October 2015 and February 2016 (Table 1).

The other cultivars showed in 2013/2014 season lower cycle duration than 'Brazos'. The flowering began in September and October to January and February, lasting 110 to 140 days and the harvest was carried out within 107 to 131 days, in the period of November/2013 to March/2014. In the following seasons the cycle duration and flowering season were similar to that observed in the first year, with small variations. Flowering period occurred during 135 to 143 days, between August/2014 and January/2015 and the harvest was carried out 102 days to 118 days between October and February. In 2014/2015 season the flowers showed in the 'Guarani', 'Tupy' and 'Xavante' cultivars up between the months of September and January with a duration of 147, 128 and 142 days, respectively. The harvest season was similar for these cultivars between November and February, held during 115 days (Table 1).

The duration of flowering and harvest period of cultivars was prolonged, different from the southern region of the country, where the flowering begins between August and September and the harvest between September and early November (CAMPAGNOLO \& PIO, 2012). Variation regarding cycle duration may be due to the due cold intensity accumulated in the period before flowering, as it is responsible for breaking dormancy and uniformity of flower buds (CLARK et al., 2005). However, in 
colder climates, there may be delay in harvesting of blackberries, because under the conditions of Pelotas, RS, Brazil even if flowering occurs between August and September, the beginning of the harvest takes place between November and December (ANTUNES et al., 2010).

In other regions, the biggest variation is related to the flowering and harvesting periods which, in the south of Brazil, last for an average 5960 days period (ANTUNES et al., 2010; BOTELHO et al., 2009; CAMPAGNOLO \& PIO, 2012). In the southeast of Brazil, the cycle varies around 117 days (CURI et al., 2015), similar to observed in this study the duration of flowering and harvesting was 134 and 118 days, respectively.

Differences observed in the present study, during the three years of cultivation, showed that both the productive period of blackberry cultivars can be related to the temperatures differences that occur in the region (Figure 1). This anticipation of production has been also observed in subtropical climates in Pelotas, Brazil (ANTUNES et al., 2010) and in western Paraná, Brazil (CAMPAGNOLO \& PIO, 2012) as well as tropical climate in Minas Gerais, Brazil (ANTUNES et al., 2006).

Information about the production time and life cycle of the blackberries cultivar in different locations is important to guide farmers who want to produce blackberries for direct consumption or for processing, because the fruit completes its development and reaches point of harvest quickly.

In addition to differences observed in duration of the production period, there was variation among cultivars regarding to the cold need to initiate flowering (Table 2). During the 2013/2014 season, the emission of floral buds was observed in 'Brazos' after an occurrence of 35 hours with temperatures below $13^{\circ} \mathrm{C}$. 'Guarani' and 'Xavante' with an accumulation of 548 hours below $13^{\circ} \mathrm{C}$ and 31 hours below $10^{\circ} \mathrm{C}$. 'Tupy' after the accumulation of 640 hours below $13^{\circ} \mathrm{C}$ and 42 hours below $10^{\circ} \mathrm{C}$ (Table 2).

The production cycle of cultivars in the studied area varied between years, likely due to temperature changes. The largest difference was noted with the 'Brazos', which showed decreased cycle during the 2014/2015 and 2015/2016 seasons. This is likely due to the lower number of hours with temperatures below $13^{\circ} \mathrm{C}$ and $10^{\circ} \mathrm{C}$, compared to the accumulation of cold in the 2013/2014 flowering period (Figure 1).

The productive period 2013/2014 for the 'Brazos' cultivar, which lasted for 254 days, may be related with the number of hours of accumulated cold: $654<13^{\circ} \mathrm{C}$ during flowering. For the $2014 / 2015$ season it was 590 hours $<13^{\circ} \mathrm{C}$ and 50 hours $<10^{\circ} \mathrm{C}$ and for the $2015 / 2016$ season, 290 hours $<13^{\circ} \mathrm{C}$ and 10 hours $<10^{\circ} \mathrm{C}$ (Table 2). This influenced the buds emission of floral buds and the start of the plants flowering time.

The other cultivar presented similar results in the following seasons. During the 2014/2015 season the emission of flower buds was observed with the accumulation of 457 hours $<13^{\circ} \mathrm{C}$ and 14 hours $<10^{\circ} \mathrm{C}$ in 'Guarani' cultivar and 473 hours $<13^{\circ} \mathrm{C}$ and 28 hours $<10^{\circ} \mathrm{C}$ in 'Tupy' and 'Xavante' cultivars. Regarding to $2015 / 2016$ season it was verified after the accumulation 269 hours $<13^{\circ} \mathrm{C}$ and 10 hours below $10^{\circ} \mathrm{C}$ (Table 2)

In the conditions of this research, the occurrence of low temperatures in the period prior to flowering was less than what is indicated in the literature, which describes requirements of 200-300 hours below $7.2^{\circ} \mathrm{C}$ (RASEIRA et al., 2007) and in the growing area where this research has performed, there were not temperatures below $7.2^{\circ} \mathrm{C}$. This indicates a need for research identifying the temperature limit for the floral induction of blackberries.

The differences presented by the blackberry cultivars may be related to factors intrinsic to the adaptation, which depends on the cold requirement and on the local climate variations (RASEIRA et al., 2007).

Results related to the beginning of flowering of cultivars showed that variations in flowering within different regions may occur, depending on the amount of cold hours accumulated by the plants resulting from temperature variations that happen from one region to another at the same region between cultivation years, as observed in this study (Figure 1).

\section{b) Effect of climate and plant variety on crop yield and productivity}

Differences observed regarding to the accumulation of cold hours with temperatures below $13^{\circ} \mathrm{C}$ and $10^{\circ} \mathrm{C}$ have also influenced the productive performance of the cultivars. During the 2013/2014 season, 'Brazos' produced an average of $4,472 \mathrm{~g}$ per plant, achieving the productivity of $22.4 \mathrm{t} \mathrm{ha}^{-1}$. 'Guarani', 'Tupy' and 'Xavante' cultivars produced 5,912; 4,290 and 1,468g per plant respectively, corresponding to a productivity of $5.9 \mathrm{tha}^{-1}, 4.3 \mathrm{tha}^{-1}$ and $1.5 \mathrm{t} \mathrm{ha}^{-1}$ (Table 3 ).

The yield of 'Brazos' in the 2013/2014 season within studied conditions is considered high for the first year of the orchard, as some authors 
Productive performance of blackberry cultivars in altitude region.

5

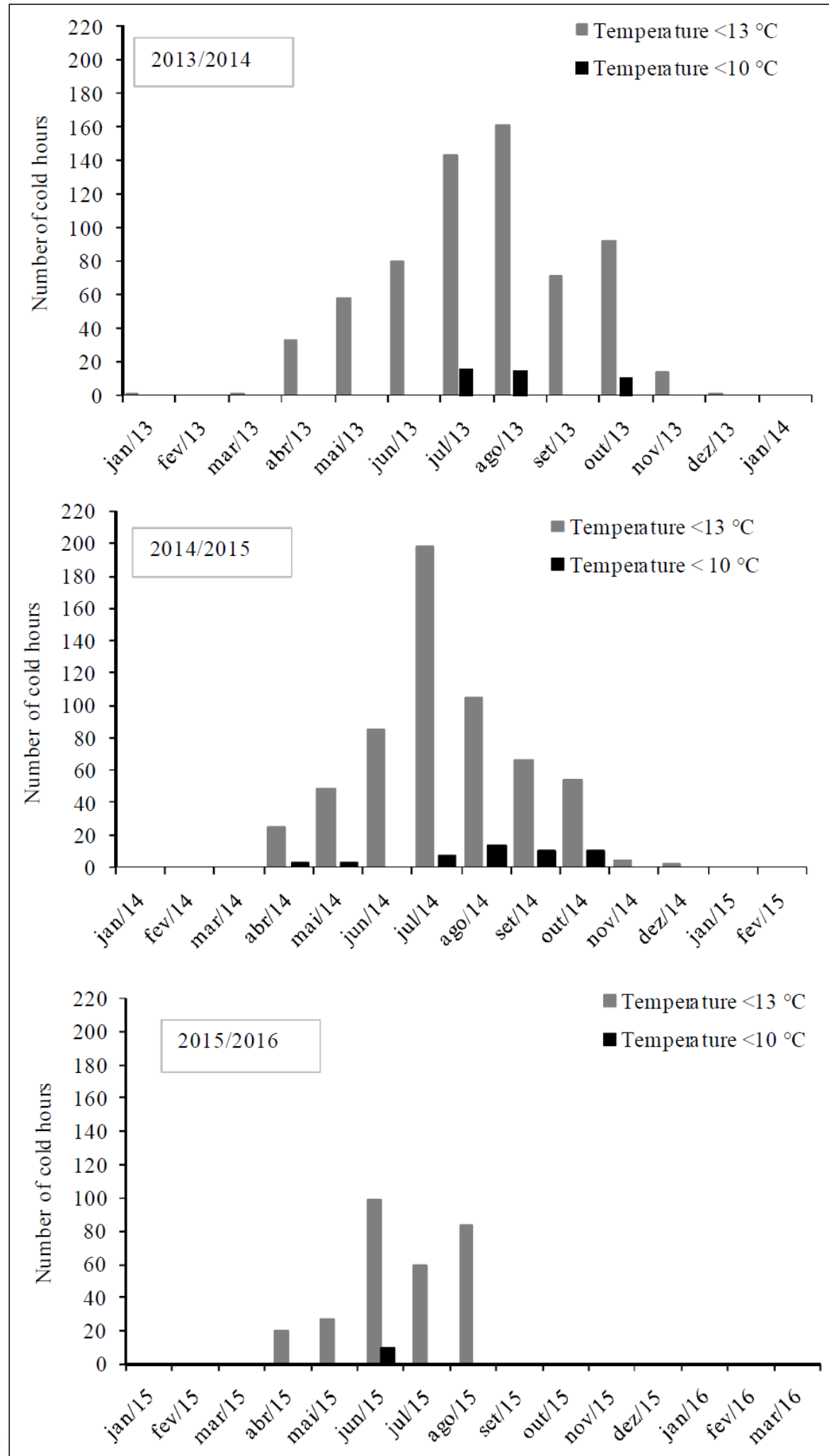

Figure 1 - Accumulation of cold hours with temperatures lower than $13^{\circ} \mathrm{C}$ and $10^{\circ} \mathrm{C}$ in $2013 / 2014$, 2014/2015 and 2015/2016 for blackberry cultivars growing in a high-altitude region.

Ciência Rural, v.47, n.12, 2017. 
Table 2 - Number of cold hours accumulated at temperatures below $13{ }^{\circ} \mathrm{C}, 10^{\circ} \mathrm{C}$ and $7.2^{\circ} \mathrm{C}$ during the cycles $2013 / 2014,2014 / 2015$ and $2015 / 2016$, for the stages of production period of blackberry cultivars in altitude region with mild temperatures.

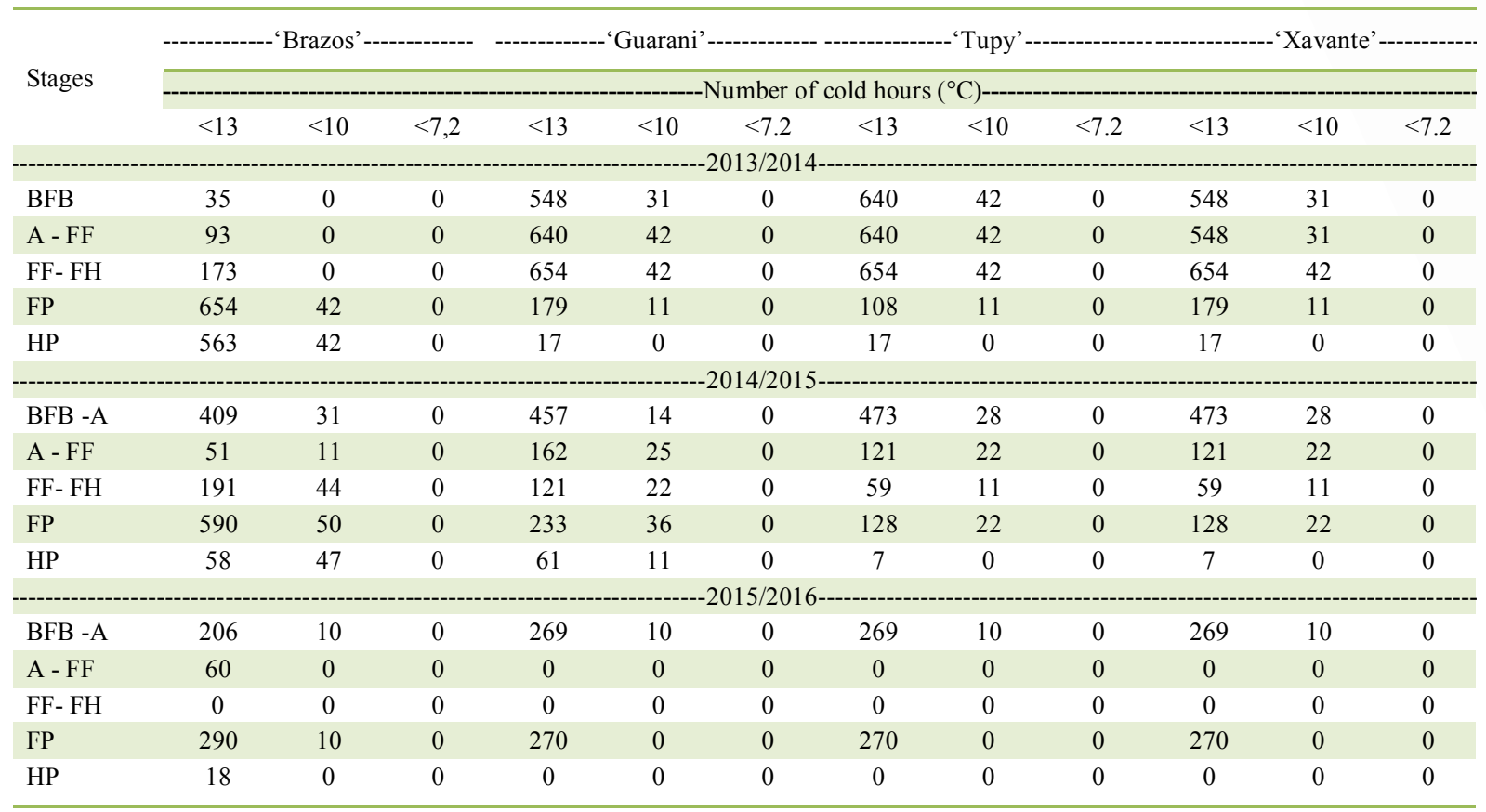

BFB - began issuing of flower buds; FFB - formation of flower buds; A - anthesis; FF = fruit formation; FH = fruit harvest; (FP) flowering period and HP - harvest period.

mentioned that this cultivar has got the potential to reach a productivity of $22 \mathrm{t} \mathrm{ha}^{-1}$ in the second year after planting (ANTUNES et al., 2014). Difference in productivity of 'Brazos' can be related to the duration of the production period of this cultivar.

The productive performance of blackberry cultivars adapted to Brazilian conditions may vary between local farming, the age of the plants and the planting density. In subtropical climate conditions, the 'Brazos' has reached productivity $18.6 \mathrm{tha}^{-1}$ in the second production cycle with the 6.667 plants per hectare planting density (CAMPAGNOLO \& PIO, 2012).

During the 2014/2015 and 2015/2016 seasons, the productive performance of 'Brazos' was lower than the previous harvest, with a production of $2,742 \mathrm{~g}$ and $3,657 \mathrm{~g}$ per plant and productivity of 13.7t ha $\mathrm{ha}^{-1}$ and $17.8 \mathrm{t} \mathrm{ha}^{-1}$ (Table 3), respectively. This may be associated with the duration of the production period (Table 1) and the temperature variations of the growing site (Figure 1). During the previous harvest, this cultivar showed good data compared to other producing regions. Furthermore, the reduction of plants' reserves may happened because of the long production cycle during 2013/2014, which resulted in the reduction the number of productive stems.

Another factor that may be related is less accumulation of chilling hours with temperatures below $13^{\circ} \mathrm{C}$ and $10^{\circ} \mathrm{C}$, which was lower in seasons 2014/2015 and 2015/2016 (Figure 1), it may have influenced the break dormancy and differentiation of flower buds.

Regarding the other cultivar, the productivities observed in the 2014/2015 and $2015 / 2016$ seasons were considered satisfactory for the productive performance that can reach from the second cycle. 'Guarani' produced on average $7.9 \mathrm{t}$ $\mathrm{ha}^{-1}$ and 9.4t ha- 'Tupy' and 4.3t ha' $\mathrm{ha}^{-1}$ and 3.0t ha $\mathrm{t}^{-1}$ and 'Xavante' 3.5 and $1.6 \mathrm{tha}^{-1}$, for the two crops respectively (Table 3 ).

The variations in the production capacity of blackberry cultivars are related to climatic elements that interfere in the budding and flowering, as well as the adopted production system, which can alter the intrinsic characteristics of the cultivar (ANTUNES et al., 2000; SWAIN \& DARNELL, 2002). In an agroecological system under conditions 
Table 3 - Crop yield and productivity of blackberry cultivars planted in a high-altitude region with mild temperatures, during 2013/2014, 2014/2015, 2015/2016 seasons.

\begin{tabular}{|c|c|c|}
\hline \multirow{2}{*}{ Cultivars } & Crop yield ( g plant $\left.^{-1}\right)$ & Productivity $\left(\mathrm{t} \mathrm{ha}^{-1}\right)^{(2)}$ \\
\hline & 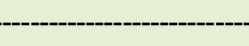 & - \\
\hline 'Brazos' & $4,472 \mathrm{~b}$ & $22.4 \mathrm{a}$ \\
\hline 'Guarani' & $5,912 \mathrm{a}$ & $5.9 \mathrm{~b}$ \\
\hline ‘Tupy’ & $4,290 \mathrm{~b}$ & $4.3 \mathrm{~b}$ \\
\hline 'Xavante' & $1,468 \mathrm{c}$ & $1.5 \mathrm{c}$ \\
\hline $\mathrm{CV}(\%)$ & 14.7 & 14.7 \\
\hline \multicolumn{3}{|l|}{------------ } \\
\hline 'Brazos’ & $2,742 \mathrm{a}$ & $13.7 \mathrm{a}$ \\
\hline 'Guarani' & $1,527 \mathrm{~b}$ & $7.6 \mathrm{~b}$ \\
\hline ‘Tupy’ & $0,851 \mathrm{c}$ & $4.3 \mathrm{c}$ \\
\hline 'Xavante' & $0,631 \mathrm{c}$ & $3.5 \mathrm{c}$ \\
\hline CV (\%) & 15.4 & 15.4 \\
\hline \multicolumn{3}{|c|}{ - } \\
\hline 'Brazos’ & $3,657 \mathrm{a}$ & $17.8 \mathrm{a}$ \\
\hline 'Guarani' & $1,872 \mathrm{~b}$ & $9.4 \mathrm{~b}$ \\
\hline ‘Tupy’ & $0,595 \mathrm{c}$ & $3.0 \mathrm{c}$ \\
\hline 'Xavante' & $0,322 \mathrm{c}$ & $1.6 \mathrm{c}$ \\
\hline CV (\%) & 20.2 & 20.2 \\
\hline
\end{tabular}

(1) Means followed by the same letter in the column do not differ by test of Tukey $(\mathrm{P} \leq 0.05)$. (2) Productivity in spaced $2.5 \mathrm{~m} x \mathrm{~m}$, with density of 5,000 plants ha ${ }^{-1}$.

of humid subtropical climate in Brazil, the average productivity within three years of 'Brazos' production was $2.8 \mathrm{t} \mathrm{ha}^{-1}$ (ANTUNES et al., 2010), lower than the productivities observed in the studied region. In the conventional cropping system the differences in productive performance of blackberry cultivars are related to the planting density and the temperature variations of region. In the state of Paraná, yields reached $15.1 \mathrm{tha}^{-1}$ by 'Guarani', 10.1t ha- 'Tupy' and $1.2 \mathrm{t} \mathrm{ha}^{-1}$ 'Xavante' with a density of $6,666 \mathrm{ha}^{-1}$ plants (CAMPAGNOLO \& PIO, 2012).

In the cultivation region of this research the variation of hours number with accumulated mild temperatures may have influenced the productive performance of the cultivars, with lower sprouting of the flower buds. In addition, the cultivars showed reduction in issuance of new stems and low nutrient content compared to those identified as ideal for blackberry in southern Brazil (ANTUNES \& RASEIRA, 2004). This suggested that is a need to adapt the nutritional management, considering the differences related to the cycle duration of cultivars in the region.

\section{CONCLUSION}

The production of the blackberry cultivars was extended in altitude region with similar productivity to the other producing regions in Brazil. The productive performance of the cultivars varied according to the accumulation of cold hours with mild temperatures that occurred in cultivation region. 'Brazos', 'Guarani', 'Tupy' and 'Xavante' showed good adaptation in altitude region, highlighting for 'Brazos' that was the most productive.

\section{ACKNOWLEDGMENTS}

The authors wish to thank Conselho Nacional de Desenvolvimento Científico e Tecnológico (CNPq) for the financial support, and the Coordenação de Aperfeiçoamento de Pessoal de Nível Superior (CAPES) for granting scholarships.

\section{REFERENCES}

ANTUNES L.E.C et al. Blackberry production in Brazil. Revista Brasileira de Fruticultura, v.36, n.1, p.100-111, 2014. Available 
from: $\quad<$ http://www.scielo.br/scielo.php?script=sci_arttext\&pid $=\mathrm{S} 0100-29452014000100012>$. Accessed: Dec. 15, 2016 .

ANTUNES, L.E.C. et al. Phenology and production of blackberry cultivars in agroecological system. Ciência Rural, v.40, n.9, p.1929-1933, 2010. Available from: <http://www.scielo.br/scielo. php? script $=$ sci_arttext\&pid $=$ S0103-84782010000900012>. Accessed: June 20, 2016.

ANTUNES, L.E.C. et al. Off season production of blackberries varieties. Revista Brasileira de Fruticultura, v.28, n.3, p.430434., 2006. Available from: <http://www.scielo.br/scielo. php?script $=$ sci_arttext\&pid $=$ S0100-29452006000300020\&lng $=$ pt \&nrm=iso>. Accessed: June 20, 2016.

ANTUNES, L.E.C. et al. Blossom and ripening periods of blackberry varieties in Brazil. Journal American Pomological Society, v.54, n.4, p.164-168, 2000. Available from: <http://www. pubhort.org/aps/54/v54_n4_a31.htm>. Accessed: June 20, 2016.

BOTELHO, R.V. et al. Phenology and yield of thornless blackbeery cv. 'Xavante' in the region of Guarapuava-PR. Scientia Agraria, v.10, n.3, p.209-214, 2009. Available from: <http://revistas.ufpr.br/ agraria/article/download/14506/9904>. Accessed: June 20, 2016.

CAMPAGNOLO, M.A.; PIO, R. Phenological and yield performance of black and redberry cultivars in western Paraná State. Acta Scientiarum. Agronomy, v.34, p.439-444, 2012. Available from: <http://www.scielo.br/scielo.php?script=sci_artte xt\&pid=S1807-86212012000400011>. Accessed: June 18, 2016.
CLARK, J.R. et al. 'Prime-Jan' ('APF-8') and 'Prime-Jim' ('APF-12') Primocane-fruiting blackberies. HortScience, v.40, p.852-855, 2005. Available from: <https://www.ars.usda.gov/ ARSUserFiles/1718/PDF/2005/Prime-Jan2005.pdf>. Accessed: June 20, 2016.

CURI, P.N. et al. Production of blackberry and redberry in Lavras - MG, Brazil. Ciência Rural, v.45, n.8, p.1368-1374, 2015. Available from: <http://dx.doi.org/10.1590/01038478cr20131572> Accessed: Dec. 15, 2016.

EMPRESA BRASILEIRA DE PESQUISA AGROPECUÁRIA (EMBRAPA). Sistema Brasileiro de Classificação de Solos. 3.ed. Brasília, 2013. 353p.

RASEIRA, A. et al. Influence of the density of plantation in the productivity of blackberry cultivars. Revista Brasileira de Agrociências, v.13, p.551-554, 2007. Available from: <https:// periodicos.ufpel.edu.br/ojs2/index.php/CAST/article/view/1400>. Accessed: June 18, 2016.

SWAIN, P.A.W.; DARNELL, R.L. Production systems influence source limitations to growth in 'Sharpblue' southern highbush blueberry. Journal American Society for Horticultural Science, v.127, n.3, p.409-414, 2002. Available from: <http:// journal.ashspublications.org/content/127/3/409. short $>$. Accessed: June 18, 2016.

VIANELlO, R.L.; ALVES, A.R. Meteorologia básica e aplicações. Viçosa: UFV, 2012. 460p. 